\title{
Can Ratios Predict the Financial Performance in Banks: A Case of National Banks in United Arab Emirates
}

\author{
(U.A.E) \\ Arindam Banerjee \\ Associate professor, Amity University, Dubai, UAE \\ E-mail: arin_006@yahoo.com
}

Received: October 19, 2018 Accepted: November 11, 2018 Published: November 18, 2018

doi:10.5296/ijafr.v8i4.13802

URL: https://doi.org/10.5296/ijafr.v8i4.13802

\begin{abstract}
A country's banking sector plays a dominant and important role in its financial growth and economic progress. The prime objective of this research paper is aimed towards evaluating the performance of 12 selected banks in United Arab Emirates (UAE) through various financial ratios. The paper highlights the various financial parameters such as adequacy of risk based capital, credit growth, concentration of credit, non performing position of loans, liquidity gap analysis, liquidity ratios, return on assets, return on equity, net interest margin in analysing the financial performance of the selected banks. The analysis of ratio helps to develop an insight to the extent the various financial variable impact the profitability and the productivity of the selected National Commercial Banks in U.A.E. The purpose of this paper is to examine the future financial performance of selected U.A.E National commercial banks using three indicators; Internal-based performance measured by Return on Assets, Market-based performance measured by Tobin's Q model (Price / Book value of Equity) and Economic-based performance measured by Economic Value add. The financial data has been adopted from the audited financial statements of the sampled banks for the period of 2014 till 2017. Statistical tools used in the study include multiple regression analysis that captures the impact of the individual size of the bank, the credit risk, efficiency in operations and the asset management on the financial performance followed by forecasting the Future Trend.
\end{abstract}

Keywords: Financial performance, Return on assets, Tobin's Q ratio, Economic value added, Operational efficiency, Asset management, Credit risk 


\section{Introduction}

The economic system of any country consists of the five integral segments, namely money, financial instruments, financial institutions, rules and regulations and the financial markets. Within the pillar of financial institutions, banks play a significant role in the fund channelization process between depositors and borrowers of finance in an effective manner. Though, for macro-economic study, we evaluate the overall efficiency of an economic system, it is equally crucial to study the contribution of the commercial banks performance separately.

In any economy, the banking system is interconnected among other banks as well as with other financial institutions. As a result, when banks turn insolvent, it affects its shareholders as well as stakeholders of the all other banks and financial institutions that are connected with it. The failure of a bank questions the financial strength of an economy. The 2008 global financial crises is a glaring example of an economic disaster resulting out of banking failure.

The UAE banking sector plays a very important role in the country's progress. It paves way for the overall development of the economy by effectively utilising the country's financial resources and supporting its economy by providing the required level of the financial support and creating the required investments for its growth.

\section{Literature Review}

Ratio analysis involves methods of calculating and interpreting financial ratios to analyse and monitor firm's performance and the basic variables used in the analysis of ratios are the firm's Financial Statements (Gitman, 2009). The main objective of analysing ratios is to evaluate the results for decision-making purposes. It also helps to identify and focus areas of weak performance and areas where there is better performance (James, 2013). By focusing on areas of good and bad performance, ratios guide the management to trace out existing strength and weakness and focus on channelized the efforts (Payne, 2011). Further, ratios help in evaluating the success or the failure of a decision by comparing in the pre and post action results (Luckham, 1982).

In a study conducted in the Australian financial institutions (Elizabeth \& Greg, 2004), reveals that the various indicators of financial performance such as margin of interest, return on assets, capital adequacy of are very much positively correlates with the Customer Service Quality Scores.

(Arzu \& Gokhan, 2005) analysed the assets liabilities management of banks in times of Financial Crisis. Their research established that the efficient management of assets and liabilities calls for profit maximisation of banks as well as controlling and regulating different types of risks.

Tarawneh (2006) applied correlations and multiple regression analysis in analysing Omani Commercial banks' financial performance. In his study, he applied the Return of Assets and the Income from the Interest as a dependent variable, and the bank size, assets management of and operational efficiency as independent variables. The research identified strong positive 
correlation between the financial performance and efficiency in the operations and a moderate correlation between Return of Assets and the Bank Size.

Khan (2013) identified that commercial banks with greater capital, additional deposits, credits, or total asset value does not essentially demonstrate the performance on the base of profitability. He also revealed that the operational efficiency and assets management coupled with bank size, strongly and positively impacted on the financial performance of the banks.

Ahmed (2011) studied the financial performance of seven Commercial Banks in Jordan. The study used the Asset Return as a measure of performance of the banks and the size of banks, assets management and operational efficiency as three independent forecasters that potentially impact the return of assets. The results obtained from his analysis showed a strong negative correlation between Return of Assets and banks size, and a strong positive correlation between Return of Assets and Asset Management Ratio and a weak negative correlation between Return of Assets and Operational Efficiency.

Ali et al.'s (2011) research on profitability of Pakistani banks recognised a noteworthy relationship between assets management, capital and economic growth and assets return. The paper established an important relationship between the equity return, operational efficiency, asset management, capital and economic growth.

In another study, Siddiqui \& Shoaib (2011) argued that bank size influences its profitability measured by the Return of Equity. The authors used Price to Book Ratio as a model for determining the performance of banks and found that Price to Book Ratio is influenced by the size of banks, leverage ratio and the investments made out by the bank.

Bashir (1999 \& 2001) observed certain relationship between profitability and characteristics of certain Islamic banks. The studies identified that profitability is a function of capital and the loan ratio and adequate capital ratios and loan portfolios impacts the performance of Islamic banks.

Samad (2004) examined the overall performance of Bahrain's commercial banks on the basis of Credit, Profitability and Liquidity ratios. By applying T -test, he showed that liquidity performance of the commercial banks were not at par with the banking industry benchmarks.

Tarawneh (2006) observed that banks having higher amounts of capital, deposits, credits and total assets does not necessarily mean that there is profitability for the bank. He identified that operational efficiency along with the bank size have a strong positive correlation with the financial performance of the banks.

The traditional measure of profitability through stockholder's equity is quite different in banking industry from any other sector of business, Jahangir, Shill and Haque (2007). The authors used loan-to-deposit ratio as banks' profitability indicator as it indicated its asset-liability management (ALM) status.

In their study, Kumbirai and Webb (2010) studied the performance of the commercial banking sector in South Africa between 2005- 2009. They applied financial ratios to measure 


\section{MInstitute ${ }^{\text {Mit }}$}

International Journal of Accounting and Financial Reporting ISSN 2162-3082

the credit quality, liquidity and profitability performance of five large South African based commercial banks.

Almazari (2011) studied seven Jordanian commercial banks and measured their financial performance from period 2005-2009. The author applied simple regression to evaluate the influence of operational efficiency, asset management and bank size and being the independent variables on interest income size and return on assets being the dependent variable. The results of the study indicated that banks that had higher shareholders' equity, credits, assets and total deposits does not necessarily mean better profitability performance.

Empirical research reveals significant differences financial performance amongst Saudi banks, Haque and Sharma (2011). The study is conducted on the basis of financial variables and ratios through the help of Spearman's' rank correlation method.

Almumani (2014) analysed and compared the performance of listed Saudi banks for the period 2007-2011 based on financial ratios and variables. Two approaches were adopted namely, trend analysis and inter-firm analysis. It was found that increasing of assets, operating expenses, and cost to income led to a decrease in Saudi bank's profitability, while increasing of operating income causes an increase in the profitability of Saudi Banks.

Tarawneh (2006) found that the banks having high total capital, deposits, credits, or total assets does not always imply that has healthier profitability performance. The operational efficiency and asset management along with the banks' size, positively influences the financial performance of these banks. Profitability is directly related with the operational efficiency, assets management ratio and asset size when using ROA as the indication of Profit, Khizer et.al. (2011).

Based on the above literature survey, it is clearly evidenced that a robust banks performance analysis needs to look beyond traditional measures and needs to include more future-looking measures that can consider elements of profitability and risk. Considering these issues, the objective of this research is to probe the future financial performance of selected U.A.E national commercial banks using three indicators; Market-based performance measured by Tobin's Q model (Price / Book value of Equity), Internal-based performance measured by Return on Assets, and Economic-based performance measured by Economic Value add, that cannot be measured by using traditional ratios.

\section{Objectives of the Study and Research Methodology}

The primary objective of this paper is to analyse the financial performance of the twenty-one selected U.A.E national banks.

\subsection{The following Are the Specific Objectives of the study}

1. To ascertain whether operational efficiency, asset management, credit risk and bank size are statistically significant impact on internal based performance (ROA) of the U.A.E National Banks. 
2. To ascertain whether operational efficiency, asset management, credit risk and bank size are statistically significant impact on market-based performance (Tobin's Q) of U.A.E National commercial banks.

3. To ascertain whether operational efficiency, asset management, credit risk and bank size are statistically significant impact on economic-based performance (EVA) of U.A.E National commercial banks.

\subsection{Hypothesis's of the Study}

In order to find answers to the research objectives and the information available from the literature review, the following hypotheses have been proposed for the study, which are:

Hypothesis 1

Ho: Operational efficiency, asset management, credit risk and bank size have no impact on internal based performance (ROA) of U.A.E National commercial banks.

HA: Operational efficiency, asset management, credit risk and bank size have significant impact on internal based performance (ROA) of UAE National commercial banks.

Hypothesis 2

Ho: Operational efficiency, asset management, credit risk and bank size have no impact on market-based performance (Tobin's Q) of U.A.E National commercial banks.

HA: Operational efficiency, asset management, credit risk and bank size have significant impact on market-based performance (Tobin's Q) of UAE National commercial banks.

Hypothesis 3

Ho: Operational efficiency, asset management, credit risk and bank size have no impact on economic-based performance (EVA) of U.A.E. National Commercial banks.

HA: Operational efficiency, asset management, credit risk and bank size have significant impact on economic -based performance (EVA) UAE National commercial banks.

\subsection{Methodology}

Considering the fact that the primary objective of this paper is to measure the financial performance the U.A.E national Banks using the three indicators, as well as to predict the future financial performance of the banks, the nature of the study is descriptive. Thus the study is based on 'Deductive Research Approach'. Additionally, quantitative analysis has been chosen for this study to analyse the data.

\subsubsection{Data}

Data pertaining to the bank size, credit risk, operational efficiency and asset management has been taken from secondary sources such as the national banks' annual reports spanning 2014-2017. 


\section{Al Macrothink}

International Journal of Accounting and Financial Reporting

ISSN 2162-3082

2018, Vol. 8, No. 4

\subsubsection{Sample Size}

The sample of the study consists of twenty-One (21), U.A.E National Commercial banks.

1. Abu Dhabi Commercial Bank P.J.S.C

2. Emirates NBD

3. Dubai Islamic Bank

4. Union National Bank

5. National Bank of Fujairah

6. United Arab Bank

7. Mashreq Bank Pjsc.

8. Sharjah Islamic Bank

9. Bank of Sharjah

10. Invest Bank Pjsc.

11. First Abu Dhabi Bank

12. Commercial Bank of Dubai

13. Ajman Bank Pjsc

14. National Bank Of Umm -Al- Quwain

15. Noor Bank

16. Al Hilal Bank

17. Arab Bank for Investment and Foreign Trade

18. Emirates Islamic Bank

19. Commercial Bank International PLC

20. National Bank of Ras Al Khaimah

21. Abu Dhabi Islamic Bank Pjsc.

Annual Time Series data for both independent and dependent variables were extracted from the respective banks' annual audited financial statements from the period 2014-2017.

\subsection{Specification of Regression Models}

In an attempt to ascertain the financial performance of the U.A.E national commercial banks, three distinct models have been established. Each of them has one dependent variable and four identical independent variables as shown in table 1. In addition, Return on Asset (ROA) was considered as an internal financial performance indicator, the Tobin's-Q model as a Market financial performance indicator and Economic Value Add (EVA) as an Economic 


\section{MlMacrothink}

International Journal of Accounting and Financial Reporting ISSN 2162-3082 2018, Vol. 8, No. 4

Financial Performance indicator. Data processing and analysis was done using SPSS. Statistical tools like Multiple Regression analysis, F-test, correlation and t-test have been used to assess and interpret data. Both F-test and t-test have been performed to test the statistical significance of the parameters at $5 \%$ level of significance.

Table 1. List of the variables to be studied

\begin{tabular}{|c|c|c|c|}
\hline $\begin{array}{l}\text { Dependent } \\
\text { Variables }\end{array}$ & Description & $\begin{array}{l}\text { Independent } \\
\text { Variables }\end{array}$ & Description \\
\hline $\begin{array}{l}\text { Return on } \\
\text { Assets (ROA) }\end{array}$ & Net Income/Total Assets & Bank Size & LOG (Total Assets) \\
\hline TOBINS Q & $\begin{array}{l}\text { Market Value of Bank / } \\
\text { Book Value of Equity }\end{array}$ & Credit Risk (CR) & $\begin{array}{l}\text { Reserve for Doubtful } \\
\text { Loans / Total Loans } \\
\text { and Advances }\end{array}$ \\
\hline \multirow[t]{2}{*}{$\begin{array}{l}\text { Economic } \\
\text { Value } \\
(\text { EVA) }\end{array}$} & $\begin{array}{l}\text { Net Operating Profit After } \\
\text { Taxes / Borrowed Capital }\end{array}$ & $\begin{array}{l}\text { Operational } \\
\text { Efficiency }(\mathrm{OE})\end{array}$ & $\begin{array}{l}\text { Total Operating } \\
\text { Expenses/ Net } \\
\text { Interest Income }\end{array}$ \\
\hline & & $\begin{array}{l}\text { Asset } \\
\text { Management } \\
(\mathrm{AM})\end{array}$ & $\begin{array}{l}\text { Operating Income / } \\
\text { Total Assets }\end{array}$ \\
\hline
\end{tabular}

Model 1: ROA $=\alpha+\beta_{1}$ Bank Size $+\beta_{2} \mathrm{CR}+\beta_{3} \mathrm{OE}+\beta_{4} \mathrm{AM}+\varepsilon$

Model 2: Tobin's $Q=\alpha+\beta_{1}$ Bank Size $+\beta_{2} \mathrm{CR}+\beta_{3} \mathrm{OE}+\beta_{4} \mathrm{AM}+\varepsilon$

Model 3: $\mathrm{EVA}=\alpha+\beta_{1}$ Bank Size $+\beta_{2} \mathrm{CR}+\beta_{3} \mathrm{OE}+\beta_{4} \mathrm{AM}+\varepsilon$

Where:

1. $\mathrm{ROA}=$ Return on Assets

2. Tobin's $\mathrm{Q}=$ Price/Book ratio

3. $\mathrm{EVA}=$ Economic Value add

4. $\quad$ Bank Size $=\log$ (assets)

5. $\mathrm{CR}=$ Credit Risk

6. $\mathrm{OE}=$ Operational Efficiency

7. $\mathrm{AM}=$ Asset Management

8. $\alpha=$ Constant term of the model

9. $\beta=$ Coefficients of the model

10. $\varepsilon=$ Error term 


\section{MlMacrothink}

International Journal of Accounting and Financial Reporting ISSN 2162-3082 2018, Vol. 8, No. 4

\section{Findings and Analysis}

\subsection{Model 1}

Dependent Variable - Return of Assets (ROA \%)

Independent Variables - Bank Size (LOG Assets), Credit Risk (CR\%), Operational Efficiency $(\mathrm{OE} \%)$ and Asset Management (AM \%),

\subsubsection{Results for Model 1}

The hypothesis being tested is

H1: Bank size, Credit Risk, Asset management and operational efficiency have impact on internal based performance (ROA) of U.A.E National commercial banks.

Therefore, the null and alternative hypotheses are:

HO: Bank size, Credit Risk, Asset management and operational efficiency have no impact on internal based performance (ROA) of U.A.E National commercial banks.

HA: Bank size, Credit Risk, Asset management and operational efficiency have significant impact on internal based performance (ROA) U.A.E National commercial banks.

Table 2. Correlation matrix

\begin{tabular}{lllllll}
\hline & & ROA \% & LOG \\
ASSETS & OE \% & AM \% & CR \% \\
\hline ROA \% & $\begin{array}{l}\text { Pearson } \\
\text { Correlation }\end{array}$ & 1 & .138 & $-.371^{* *}$ & $.463^{* *}$ & -.188 \\
\cline { 2 - 7 } & Sig. (2-tailed) & & .212 & .001 & .000 & .087 \\
\cline { 2 - 7 } & N & 84 & 84 & 84 & 84 & 84 \\
\hline ASSETS & $\begin{array}{l}\text { Pearson } \\
\text { Correlation }\end{array}$ & .138 & 1 & .042 & .020 & .060 \\
\cline { 2 - 7 } & Sig. (2-tailed) & .212 & & .702 & .858 & .589 \\
\cline { 2 - 7 } & N & 84 & 84 & 84 & 84 & 84 \\
\hline \multirow{2}{*}{ OE \% } & $\begin{array}{l}\text { Pearson } \\
\text { Correlation }\end{array}$ & $-.371^{* *}$ & .042 & 1 & -.187 & -.175 \\
\cline { 2 - 7 } & Sig. (2-tailed) & .001 & .702 & & .089 & .112 \\
\hline
\end{tabular}




\begin{tabular}{lllllll}
\hline & $\mathrm{N}$ & 84 & 84 & 84 & 84 & 84 \\
\hline AM \% & $\begin{array}{l}\text { Pearson } \\
\text { Correlation }\end{array}$ & $.463^{* *}$ & .020 & -.187 & 1 & .027 \\
\cline { 2 - 7 } & Sig. (2-tailed) & .000 & .858 & .089 & & .805 \\
\cline { 2 - 7 } & $\mathrm{N}$ & 84 & 84 & 84 & 84 & 84 \\
\hline CR \% & $\begin{array}{l}\text { Pearson } \\
\text { Correlation }\end{array}$ & -.188 & .060 & -.175 & .027 & 1 \\
\cline { 2 - 7 } & Sig. (2-tailed) & .087 & .589 & .112 & .805 & \\
\cline { 2 - 7 } & $\mathrm{N}$ & 84 & 84 & 84 & 84 & 84 \\
\hline
\end{tabular}

**. Correlation is significant at the 0.01 level (2-tailed).

After the Analysis of the Table 2 we can deduce the following:

1. There is positive correlation between return of assets (ROA) and the asset management of the bank (AM\%), but it is weakly correlated

2. There is a positive correlation between return of assets(ROA) and the bank size $(\log )$ assets, but it the correlation is weak

3. There is a negative correlation between the return of assets (ROA) and the operational efficiency $(\mathrm{OE} \%)$

4. There is a negative correlation between the return of assets (ROA) and the credit risk management $(\mathrm{CR} \%)$

Table 3. Model summary

\begin{tabular}{|c|c|c|c|c|c|c|c|c|c|}
\hline \multirow[t]{2}{*}{ Model } & \multirow[t]{2}{*}{$\mathrm{R}$} & \multirow{2}{*}{$\begin{array}{l}\mathrm{R} \\
\text { Square }\end{array}$} & \multirow{2}{*}{$\begin{array}{l}\text { Adjusted } \\
\text { R Square }\end{array}$} & \multirow{2}{*}{$\begin{array}{l}\text { Std. Error } \\
\text { of the } \\
\text { Estimate }\end{array}$} & \multicolumn{5}{|c|}{ Change Statistics } \\
\hline & & & & & $\begin{array}{l}\mathrm{R} \\
\text { Square } \\
\text { Change }\end{array}$ & $\begin{array}{l}\text { F } \\
\text { Change }\end{array}$ & df1 & $\mathrm{df} 2$ & $\begin{array}{l}\text { Sig. F } \\
\text { Change }\end{array}$ \\
\hline 1 & $.623^{\mathrm{a}}$ & .389 & .358 & .80461 & .389 & 12.553 & 4 & 79 & .000 \\
\hline
\end{tabular}

a. Predictors: (Constant), CR \%, AM \%, LOG ASSETS, OE \% 


\section{Macrothink}

International Journal of Accounting and Financial Reporting

ISSN 2162-3082

2018, Vol. 8, No. 4

Referring to the Table 3, the Adjusted R - Square value is .358, which means $35.8 \%$. of the Variation in the Dependent Variable Return on Assets (ROA) is explained by the Independent Variables Bank Size (LOG Assets), Asset Management (AM), Operational Efficiency (OE) and Credit Risk (CR).

Table 4. ANOVA ${ }^{\mathrm{a}}$

\begin{tabular}{|c|c|c|c|c|c|c|}
\hline \multicolumn{2}{|c|}{ Model } & \multirow{2}{*}{$\begin{array}{l}\text { Sum of Squares } \\
32.508\end{array}$} & \multirow{2}{*}{$\frac{\mathrm{df}}{4}$} & \multirow{2}{*}{$\begin{array}{l}\text { Mean Square } \\
8.127\end{array}$} & \multirow{2}{*}{$\begin{array}{l}\mathrm{F} \\
12.553\end{array}$} & \multirow{2}{*}{$\begin{array}{l}\text { Sig. } \\
.000^{\mathrm{b}}\end{array}$} \\
\hline 1 & Regression & & & & & \\
\hline & Residual & 51.144 & 79 & .647 & & \\
\hline & Total & 83.652 & 83 & & & \\
\hline
\end{tabular}

a. Dependent Variable: ROA \%

b. Predictors: (Constant), CR \%, AM \%, LOG ASSETS, OE \%

From the Table above, it is known that the Value of F-Stat is 12.553 , with df values $(4,79)$ and is Significant as the level of Significance is less than $1 \%$ or 0.01 , hence, we can conclude that, there is overall significant relationship between the predictors i.e. the independent variables (Bank Size, Operational Efficiency, Credit Risk and Asset Management as a Group and they Predict the Independent Variable (Return of Assets) Significantly.

So, we reject the Null Hypothesis: and accept the Alternate Hypothesis.

\subsubsection{Accept}

HA: Bank size, Credit Risk, Asset management and operational efficiency have significant impact on internal based performance (ROA) U.A.E National commercial banks.

Table 5. Coefficients

\begin{tabular}{|c|c|c|c|c|c|c|c|c|}
\hline \multirow{2}{*}{\multicolumn{2}{|c|}{ Model }} & \multicolumn{2}{|c|}{$\begin{array}{l}\text { Unstandardized } \\
\text { Coefficients }\end{array}$} & \multirow{2}{*}{$\begin{array}{l}\text { Standardized } \\
\text { Coefficients } \\
\text { Beta }\end{array}$} & \multirow[t]{2}{*}{$\mathrm{t}$} & \multirow[t]{2}{*}{ Sig. } & \multicolumn{2}{|c|}{$\begin{array}{l}95.0 \% \\
\text { Confidence } \\
\text { Interval for B }\end{array}$} \\
\hline & & $\mathrm{B}$ & Std. Error & & & & $\begin{array}{l}\text { Lower } \\
\text { Bound }\end{array}$ & $\begin{array}{l}\text { Upper } \\
\text { Bound }\end{array}$ \\
\hline \multirow[t]{2}{*}{1} & (Constant) & 2.053 & .308 & & 6.668 & .000 & 1.440 & 2.666 \\
\hline & LOG ASSETS & .823 & .452 & .161 & 1.819 & .073 & -.078 & 1.723 \\
\hline
\end{tabular}




\begin{tabular}{|c|c|c|c|c|c|c|c|}
\hline & 10 & & International & Journal of Accou & ting and & $\begin{array}{r}\text { Financial } \\
\text { ISSN } \\
2018, \text { Vo }\end{array}$ & $\begin{array}{l}\text { Reporting } \\
2162-3082 \\
8, \text { No. } 4\end{array}$ \\
\hline $\mathrm{OE} \%$ & -.015 & .004 & -.350 & -3.842 & .000 & -.023 & -.007 \\
\hline AM \% & .210 & .047 & .402 & 4.487 & .000 & .117 & .303 \\
\hline $\mathrm{CR} \%$ & -.142 & .047 & -.269 & -3.007 & .004 & -.236 & -.048 \\
\hline
\end{tabular}

a. Dependent Variable: ROA \%

Thus, the analysis predicts the Return of Assets with about $35.8 \%$ explanatory power by the Following model:

$$
\begin{aligned}
\mathrm{ROA} & =2.053+.823 \mathrm{Log} \text { Assets (Bank Size })+-.015 \mathrm{OE}(\text { Operational Efficiency }) \\
+ & .210 \mathrm{AM} \text { (Asset Management })+-.142 \mathrm{CR}(\text { Credit Risk })+\mathrm{E}(\text { Error })
\end{aligned}
$$

To assess the Significance of Each Independent Variable on the Dependent variable Return of Assets, it has been established that the Operational Efficiency (OE), Asset Management (AM), and Credit Risk (CR) have Significant Impact on the Return of Assets (ROA) as their T- sig are less than 5\%. But the Bank Size (Log Assets) do not have any Significance on the Return of Assets as its T-Sig is > than $5 \%$

\subsection{Model 2}

Dependent Variable - Tobin's Q (PB Ratio)

Independent Variables - Bank Size (LOG Assets), Operational Efficiency (OE\%) Asset Management (AM \%), Credit Risk (CR\%).

\subsubsection{Results for Model 2}

The hypothesis being tested is

H2: Bank size, Credit Risk, Asset management and operational efficiency have impact on market-based performance (Tobin's Q) of U.A.E National commercial banks

Therefore, the null and alternative hypotheses are:

HO: Bank size, Credit Risk, Asset management and operational efficiency have no impact on market-based performance (Tobin's Q) of U.A.E National commercial banks.

HA: Bank size, Credit Risk, Asset management and operational efficiency have significant impact on market-based performance (Tobin's Q) of U.A.E National commercial banks

Table 6. Correlations

\begin{tabular}{llllll}
\hline TOBIN & LOG & CR \% & AM & OE \\
S Q & ASSET & & $\%$ & $\%$ \\
& & & & & \\
\hline
\end{tabular}




\begin{tabular}{|c|c|c|c|c|c|c|}
\hline \multirow[t]{3}{*}{ TOBINS Q } & Pearson Correlation & 1 & .069 & .025 & $.262^{*}$ & .076 \\
\hline & Sig. (2-tailed) & & .534 & .819 & .016 & .490 \\
\hline & $\mathrm{N}$ & 84 & 84 & 84 & 84 & 84 \\
\hline \multirow[t]{3}{*}{ LOG ASSETS } & Pearson Correlation & .69 & 1 & .060 & .020 & .042 \\
\hline & Sig. (2-tailed) & .534 & & .589 & .858 & .702 \\
\hline & $\mathrm{N}$ & 84 & 84 & 84 & 84 & 84 \\
\hline \multirow[t]{3}{*}{$\mathrm{CR} \%$} & Pearson Correlation & .025 & .060 & 1 & .027 & -.175 \\
\hline & Sig. (2-tailed) & .819 & .589 & & .805 & .112 \\
\hline & $\mathrm{N}$ & 84 & 84 & 84 & 84 & 84 \\
\hline \multirow[t]{3}{*}{ AM \% } & Pearson Correlation & $.262^{*}$ & .020 & .027 & 1 & -.187 \\
\hline & Sig. (2-tailed) & .016 & .858 & .805 & & .089 \\
\hline & $\mathrm{N}$ & 84 & 84 & 84 & 84 & 84 \\
\hline \multirow[t]{3}{*}{$\mathrm{OE} \%$} & Pearson Correlation & .076 & .042 & -.175 & -.187 & 1 \\
\hline & Sig. (2-tailed) & .490 & .702 & .112 & .089 & \\
\hline & $\mathrm{N}$ & 84 & 84 & 84 & 84 & 84 \\
\hline
\end{tabular}

*Correlation is significant at the 0.05 level (2-tailed).

From the analysis of table 6, we can deduce the following:

1. There is a positive but very weak correlation between the bank size (log assets) and the Tobin's q ratio

2. There is a positive but very weak correlation between credit risk (\%) and Tobin's q ratio

3. There is a positive but very weak correlation between asset management and Tobin's q ratio.

4. There is a positive but weak correlation between operational efficiency and Tobin's q ratio. 
So, in overall there is very weak correlation between the independent and the dependent variables and which is insignificant.

Table 7. Model summary

\begin{tabular}{|c|c|c|c|c|c|c|c|c|c|}
\hline \multirow[t]{2}{*}{ Model } & \multirow[t]{2}{*}{$\mathrm{R}$} & \multirow{2}{*}{$\begin{array}{l}\mathrm{R} \\
\text { Square }\end{array}$} & \multirow{2}{*}{$\begin{array}{l}\text { Adjuste } \\
\text { d R } \\
\text { Square }\end{array}$} & \multirow{2}{*}{$\begin{array}{l}\text { Std. Error } \\
\text { of the } \\
\text { Estimate }\end{array}$} & \multicolumn{5}{|c|}{ Change Statistics } \\
\hline & & & & & $\begin{array}{l}\mathrm{R} \text { Square } \\
\text { Change }\end{array}$ & $\begin{array}{l}\text { F } \\
\text { Change }\end{array}$ & df1 & $\mathrm{df} 2$ & $\begin{array}{l}\text { Sig. F } \\
\text { Change }\end{array}$ \\
\hline 1 & $.300^{\mathrm{a}}$ & .090 & .044 & 1.45286 & .090 & 1.948 & 4 & 79 & .111 \\
\hline
\end{tabular}

a. Predictors: (Constant), CR \%, AM \%, LOG ASSETS, OE \%

The Adjusted R Square value is .044 , which means only $4.4 \%$ variation of Dependent Variable (Tobin's Q) is due to the Independent Variables (Bank Size, Credit Risk, Asset Management and Operational Efficiency).

Table 8. ANOVA ${ }^{\mathrm{a}}$

\begin{tabular}{lllllll}
\hline Model & & Sum of Squares & df & Mean Square & F & Sig. \\
\hline 1 & Regression & 16.443 & 4 & 4.111 & 1.948 & $.111^{\mathrm{b}}$ \\
\cline { 2 - 6 } & Residual & 166.754 & 79 & 2.111 & & \\
\cline { 2 - 6 } & Total & 183.197 & 83 & & & \\
\hline
\end{tabular}

a. Dependent Variable: TOBINS Q

b. Predictors: (Constant), CR \%, AM \%, LOG ASSETS, OE \%

From the Table it is Known that the F stat is 1.948 with df values $(4,20)$, but the Significance value is above $5 \%$ or 0.05 , which means there is no Signifance between the Independent Variables and the Dependent Variable.

Hence, we Conclude that there is No Significant Relationship the Independent Variables Bank Size (LOG Assets), Operational Efficiency (OE\%), Asset Management (AM \%) Credit Risk (CR\%) and the Dependent Variable - Tobin's Q (PB Ratio).

So, we Accept Null Hypothesis and Reject Alternate Hypothesis

\subsubsection{Accept}

HO: Bank size, Credit Risk, Asset management and operational efficiency have no impact on market-based performance (Tobin's Q) of U.A.E National commercial banks. 
Table 9. Coefficients

\begin{tabular}{|c|c|c|c|c|c|c|c|c|}
\hline \multicolumn{2}{|c|}{ Model } & \multicolumn{2}{|c|}{$\begin{array}{l}\text { Unstandardize } \\
\text { d Coefficients }\end{array}$} & \multirow{2}{*}{$\begin{array}{l}\text { Standardized } \\
\text { Coefficients } \\
\text { Beta }\end{array}$} & \multirow[t]{2}{*}{$\mathrm{t}$} & \multirow[t]{2}{*}{ Sig. } & \multicolumn{2}{|c|}{$\begin{array}{l}95.0 \% \text { Conf } \\
\text { Interval for B }\end{array}$} \\
\hline & & B & $\begin{array}{l}\text { Std. } \\
\text { Error }\end{array}$ & & & & $\begin{array}{l}\text { Lower } \\
\text { Bound }\end{array}$ & $\begin{array}{l}\text { Upper } \\
\text { Bound }\end{array}$ \\
\hline \multirow[t]{5}{*}{1} & (Constant) & .257 & .556 & & .462 & .645 & -.850 & 1.364 \\
\hline & $\begin{array}{l}\text { LOG } \\
\text { ASSETS }\end{array}$ & .419 & .817 & .055 & .513 & .609 & -1.207 & 2.045 \\
\hline & OE \% & .009 & .007 & .134 & $\begin{array}{l}1.20 \\
4\end{array}$ & .232 & -.006 & .023 \\
\hline & AM \% & .220 & .084 & .285 & $\begin{array}{l}2.60 \\
8\end{array}$ & .011 & .052 & .388 \\
\hline & $\mathrm{CR} \%$ & .029 & .085 & .038 & .344 & .732 & -.140 & .199 \\
\hline
\end{tabular}

a. Dependent Variable: TOBINS Q

On analysing the Table above, we can understand that the Independent Variables Bank Size (Log Assets), Operational Efficiency, Credit Risk have T -Sig value > .05 or 5\%, which means that they are not Significant Predictors of the Independent Variable Tobin's Q

The Independent Variable Asset Management has $\mathrm{T}-\mathrm{Sig}$ value which is $<.05$ or $5 \%$, which means that it is the only Significant Predictor of the Independent Variable Tobin's Q among all other Independent Variables.

\subsection{Model 3}

Dependent Variable - Economic Value Add

Independent Variables - Bank Size (LOG Assets), Operational Efficiency (OE\%) Asset Management (AM \%), Credit Risk (CR\%).

\subsubsection{Result for Model 3}

H3: Bank size, Credit Risk, Asset management and operational efficiency have impact on economic-based performance (EVA) of U.A.E National commercial banks.

Therefore, the null and alternative hypotheses are:

HO: Bank size, Credit Risk, Asset management and operational efficiency have no impact on economic-based performance (EVA) of U.A.E National commercial banks. 


\section{Ml Macrothink}

International Journal of Accounting and Financial Reporting ISSN 2162-3082

HA: Bank size, Credit Risk, Asset management and operational efficiency have significant impact on economic -based performance (EVA) of U.A.E National commercial banks.

Table 10. Correlations

\begin{tabular}{|c|c|c|c|c|c|c|}
\hline & & EVA $\%$ & $\begin{array}{l}\text { LOG } \\
\text { ASSE } \\
\text { TS }\end{array}$ & $\mathrm{CR} \%$ & $\begin{array}{l}\mathrm{AM} \\
\%\end{array}$ & $\mathrm{OE} \%$ \\
\hline \multirow[t]{3}{*}{$\mathrm{EV} \mathrm{A} \%$} & Pearson Correlation & 1 & .052 & $-.377^{* *}$ & .108 & $.267^{*}$ \\
\hline & Sig. (2-tailed) & & .638 & .000 & .328 & .014 \\
\hline & $\mathrm{N}$ & 84 & 84 & 84 & 84 & 84 \\
\hline \multirow[t]{3}{*}{ LOG ASSETS } & Pearson Correlation & .052 & 1 & .060 & .020 & .042 \\
\hline & Sig. (2-tailed) & .638 & & .589 & .858 & .702 \\
\hline & $\mathrm{N}$ & 84 & 84 & 84 & 84 & 84 \\
\hline \multirow[t]{3}{*}{$\mathrm{CR} \%$} & Pearson Correlation & $-.377^{* *}$ & .060 & 1 & .027 & -.175 \\
\hline & Sig. (2-tailed) & .000 & .589 & & .805 & .112 \\
\hline & $\mathrm{N}$ & 84 & 84 & 84 & 84 & 84 \\
\hline \multirow[t]{3}{*}{$\mathrm{AM} \%$} & Pearson Correlation & .108 & .020 & .027 & 1 & -.187 \\
\hline & Sig. (2-tailed) & .328 & .858 & .805 & & .089 \\
\hline & $\mathrm{N}$ & 84 & 84 & 84 & 84 & 84 \\
\hline \multirow[t]{3}{*}{$\mathrm{OE} \%$} & Pearson Correlation & $.267^{*}$ & .042 & -.175 & -.187 & 1 \\
\hline & Sig. (2-tailed) & .014 & .702 & .112 & .089 & \\
\hline & $\mathrm{N}$ & 84 & 84 & 84 & 84 & 84 \\
\hline
\end{tabular}

**Correlation is significant at the 0.01 level (2-tailed).

*Correlation is significant at the 0.05 level (2-tailed). 


\section{Al Macrothink}

International Journal of Accounting and Financial Reporting

ISSN 2162-3082

2018, Vol. 8, No. 4

On analysing table 10, we can deduce the following

1. There is positive moderate correlation between the independent variable bank size and the dependent variable economic value added (EVA)

2. There is negative correlation between the credit risk and economic value added (EVA)

3. There is a positive but very weak correlation between the asset management and economic value added (EVA)

4. There is a positive but very weak correlation between the operational efficiency and the economic value added (EVA)

Table 11. Model summary

\begin{tabular}{|c|c|c|c|c|c|c|c|c|c|}
\hline \multirow[t]{2}{*}{ Model } & \multirow[t]{2}{*}{$\mathrm{R}$} & \multirow{2}{*}{$\begin{array}{l}\mathrm{R} \\
\text { Square }\end{array}$} & \multirow{2}{*}{$\begin{array}{l}\text { Adjuste } \\
\mathrm{d} \quad \mathrm{R} \\
\text { Square }\end{array}$} & \multirow{2}{*}{$\begin{array}{l}\text { Std. Error } \\
\text { of the } \\
\text { Estimate }\end{array}$} & \multicolumn{5}{|c|}{ Change Statistics } \\
\hline & & & & & $\begin{array}{l}\text { R Square } \\
\text { Change }\end{array}$ & $\begin{array}{l}\text { F } \\
\text { Change }\end{array}$ & $\mathrm{df} 1$ & $\mathrm{df} 2$ & $\begin{array}{l}\text { Sig. F } \\
\text { Change }\end{array}$ \\
\hline 1 & $.461^{\mathrm{a}}$ & .212 & .172 & 17.11828 & .212 & 5.324 & 4 & 79 & .001 \\
\hline
\end{tabular}

a. Predictors: (Constant), CR \%, AM \%, LOG ASSETS, OE \%

The Adjusted R Square Value is just .172 which is $17.2 \%$, that means the Independent Variables or predictors which Includes Credit Risk, Asset Management, LOG Assets, Operational Efficiency are only able to make $17.2 \%$ Variations on the Dependent Variable Economic Value Added (EVA).

Table 12. ANOVA ${ }^{\mathrm{a}}$

\begin{tabular}{lllllll}
\hline \multirow{2}{*}{ Model } & $\begin{array}{l}\text { Sum } \\
\text { Squares }\end{array}$ & of & df & $\begin{array}{l}\text { Mean } \\
\text { Square }\end{array}$ & F & Sig. \\
\hline 1 & Regression & 6241.065 & 4 & 1560.266 & 5.324 & $.001^{\mathrm{b}}$ \\
\cline { 2 - 7 } & Residual & 23149.807 & 79 & 293.036 & & \\
\cline { 2 - 6 } & 29390.872 & 83 & & & \\
\hline
\end{tabular}

a. Dependent Variable: E V A \%

b. Predictors: (Constant), CR \%, AM \%, LOG ASSETS, OE \%. 


\section{MlMacrothink}

International Journal of Accounting and Financial Reporting

ISSN 2162-3082

2018, Vol. 8, No. 4

From the ANOVA table above, we can understand that the F - Sig Value is .001 which is less than .05 or $5 \%$ that means Hence, we can Conclude that, there is Overall Significant Relationship between the Predictors i.e. the Independent Variables (Bank Size (LOG Assets), Operational Efficiency (OE\%), Asset Management (AM \%), Credit Risk (CR\%) and the Dependent Variable Economic Value Added as a group and they can predict the Dependent Variable.

So, We Reject Null Hypothesis and Accept Alternate Hypothesis

\subsubsection{Accept}

HA: Bank size, Credit Risk, Asset management and operational efficiency have significant impact on economic -based performance (EVA) of U.A.E National commercial banks.

Table 13. Coefficients ${ }^{\mathrm{a}}$

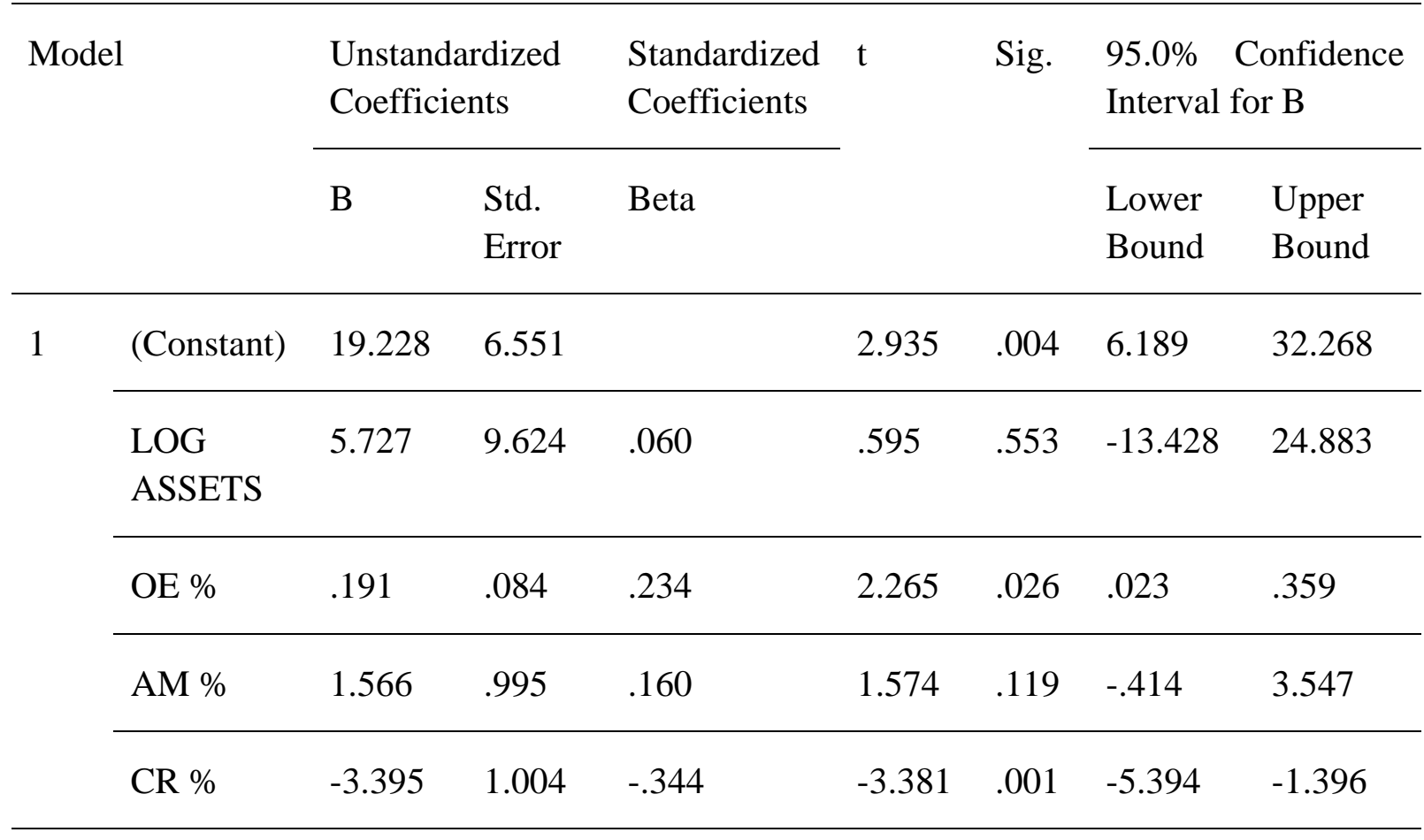

a. Dependent Variable: E V A \%

The Economic Value Added is predicted with $17.2 \%$ explanatory power by the Following Model.

$\mathrm{EVA}=19.228+5.727$ BANK SIZE (LOG Assets) +.191 OE (Operational Efficiency)

$$
\text { + 1.566 AM (Asset Management) + -3.395 Credit Risk (CR\%) }
$$

While Assessing the Significance level of the Independent Variables i.e. the Predictors we can understand that the Operational Efficiency (OE\%) and the Credit Risk (CR \%) have T Sig value which is < than .05, that means they have Significant Impact on the Dependent Variable Economic Value Added and they can predict it. 


\section{Macrothink}

International Journal of Accounting and Financial Reporting

ISSN 2162-3082

Meanwhile the Predictors Bank Size (LOG Assets), and Asset Management (AM \%) have T - Sig Value which is >.05 and they do not have any Significant Impact on the Dependent Variable Economic Value Added (EVA).

\section{Conclusion}

In order to determine the performance of the U.A.E National Commercial Banks, this paper considered the data from 21 National Commercial Banks and measured their performance at three levels, internal performance, market performance and economic performance internal performance was measured by using the ROA, Market based Performance was done by Tobin's Q method and the Economic Performance was measured by means of Economic Value Added. From the 3 Regression model, the First Model tested on Internal Based Performance that has been done by taking the ROA as dependent Variable, it was found that $35.8 \%$ of the variations of the dependant variable was due to the Independent Variables. In addition, seeing in to the Significance of each of the Independent Variable, on the Dependent variable Return of Assets, it has been established that the Operational Efficiency (OE), Asset Management (AM), and Credit Risk (CR) have Significant Impact on the Return of Assets (ROA) as their T- sig are less than 5\%. But the Bank Size (Log Assets) does not have any significance on the Return of Assets as its $\mathrm{T}-\mathrm{Sig}$ is $>5 \%$.

While analysing the Market Based Performance it was found that there is only $4.4 \%$ variation on the Dependent Variable Tobin's Q was by the Respective Independent Variables. The Independent Variables Bank Size (Log Assets), Operational Efficiency, Credit Risk have T -Sig value > .05 or $5 \%$, which means that they are not Significant Predictors of the Independent Variable Tobin's The Independent Variable Asset Management has T - Sig value which is $<.05$ or $5 \%$, which means that it is the only Significant Predictor of the Independent Variable Tobin's Q among all other Independent Variables.

In the Third model the Economic Value Added, it was found that $17.2 \%$ of the variations of the dependent Variable was due to the Independent Variables. In addition, seeing in to the Significance of each of the Independent Variable i.e. the Predictors we can understand that the Operational Efficiency (OE\%) and the Credit Risk (CR \%) have T - Sig value which is < than .05, that means they have Significant Impact on the Dependent Variable Economic Value Added and they can predict it. Meanwhile the Predictors Bank Size (LOG Assets), and Asset Management (AM \%) have T - Sig Value which is $>.05$ and they do not have any Significant Impact on the Dependent Variable Economic Value Added (EVA).

The above study can assist banks' management to focus on areas of extreme importance that has potentially stronger influence on banks' performance. Further, unlike the traditional ratio analysis measured on retrospective method that is based on accounting data as compared to economic data, this study can lead to further research.

\subsection{Limitations of the Study}

A few limitations of the research are stated below: 


\section{Ml Macrothink}

International Journal of Accounting and Financial Reporting

ISSN 2162-3082

2018, Vol. 8, No. 4

Considering the time limitation and busy schedules of interviewers, direct interview of employees from the National Commercial banks could not be conducted which otherwise could have resulted in the better understanding of the internal performance of the bank. Further, the sample size included data of twenty-one national banks for four years. An increased sample size could have improved the robustness of the research. Finally, the research being mainly dependent on secondary sources, its results and accuracy primarily depended completely on the financial statements used.

\subsection{Directions for Further Research}

Based on the above research and its findings, research can be done with primary data. This can be conducted through interviews of bankers with sample from state owned NCBs and non-state owned FCBs. The sample can be a mix of urban and rurally located banks. Results of the interviews can add to the quantitative data used in the above research and help improve the finding of this research. Additionally, further performance variables can be looked into and added to the study.

\section{Acknowledgement}

The author acknowledges the help of Mr. Prince Francis, MBA student of Amity University, Dubai for his valuable contribution in the paper.

\section{References}

Ahmed, A. A. (2011). Financial Performance Evaluation of Some Selected Jordanian Commercial Banks. International Research Journal of Finance and Economics, 6(4), 50-63.

Ali, K., Akhtar, M., \& Ahmed, H. (2011). Bank-Specific and Macroeconomic Indicators of Profitability - Empirical Evidence from the Commercial Banks of Pakistan. International Journal of Business and Social Science, 2(6), 235-242.

Almazari. A. A. (2011). Financial performance evaluation of some selected Jordanian commercial banks. International Research Journal of Finance and Economics.

Almumani, M. A. (2014). A comparison of financial performance of Saudi banks. Asian Journal of Research in Banking and Finance, 4(2), 18-20.

Arzu, T., \& Gokhan, G. (2005). Asset and Liability management in financial crises. The Journal of Risk Finance, 6(2), 35-49.

Bashir, A.-H. M. (1999). Risk and Profitability Measures in Islamic Banks: the Case of Two Sudanese Banks. Islamic Economic Studies, 6(2).

Bashir, A.-H. M. (2001). Assessing the performance of Islamic banks: Some evidence from the Middle East. Topics in Middle Eastern and North African Economies, 30. Retrieved from http://ecommons.luc.edu/meea/30

Brigham, E. F., \& Houston, J. F. (2011). Fundamentals of Financial Management (10th ed.). Ohio, USA: Thomson South Western. 
Dhanabhakyam, M., \& Kavitha, M. (2012). Financial Performance of selected Public-sector banks in India. International Journal of Multidisciplinary Research, 2(1), 255- 269.

Elizabeth, D., \& Greg, E. (2004). Efficiency, customer service and financial performance among Australian financial Institutions. International Journal of Bank Marketing, 22(5), 319-342.

Gitman, L. J. (2009). Principles of Managerial Finance (12th ed.). New York: Prentice Hall.

Guise, M. L. (2012). Financial Performance of the Malaysian Banking Industry: Domestic vs. Foreign Banks. Institute of Graduate Studies and Research.

Haque, M. I., \& Sharma, B. (2011). Benchmarking Financial Performance of Saudi Banks using Regression. International Journal of Business Economics and Management Research, 2(1), 2229-4848.

Iqbal, M. J. (2012). Banking sector's performance in Bangladesh-An application of selected CAMELS ratio. A project submitted in partial fulfilment of the requirements for the degree of Professional Master in Banking and Finance, Asian Institute of Technology, Thailand.

Jahangir, N., Shill, S., Haque, M. D., \& Jahid, A. (2007). Examination of profitability in the context of Bangladesh banking industry. ABAC Journal, 27(2), 36-46.

James, K. (2013). What Are the Types of Financial Ratios Used to Analyse Financial Performance?. African Journal of Business Management, 5(35), 235- 269.

Khan, A. R. (2013). Bank Management: A Fund Emphasis. Dhaka: Brothers Publications.

Khizer, A., Muhammad, F. A., \& Sharma, S. (2011). Financial and non-financial business risk perspectives: empirical evidence from commercial banks. Middle Eastern Finance and Economics, 11, 151-159.

Kumbirai, M., \& Webb, R. (2010). A financial ratio analysis of commercial performance in South Africa. African Review of Economics and Finance, 2(1), 30-53.

Luckham, W. R. (1982). Financial Ratio Analysis for Decision-Making. Journal of Arboriculture, 8(11), 296-301.

Madhura, J. (2009). Financial markets and Institutions (7th ed.). USA: Thomson South Western.

Nguyen C. V., Islam A. M., \& Ali, M. M. (2011). The Current State of the Financial Sector of Bangladesh: An Analysis. AIUB Bus Econ Working Paper Series, No. 2011-03.

Payne, R. (2011). Finance's Role in the Organization. Institute of Chartered Accountants in England and Wales.

Rashid, M. (2010, September 19). Banking Sector Challenges in Bangladesh. The Daily Star.

Samad, A. (2004). Performance of Interest-free Islamic banks vis-à-vis Interest-based Conventional Banks of Bahrain. IIUM Journal of Economics and Management, 12(2). 


\section{Macrothink}

International Journal of Accounting and Financial Reporting ISSN 2162-3082 2018, Vol. 8, No. 4

Searle, P. (2008). What is the role of finance? And what exactly is decision support?. Finance Director Europe. Cornhill Publication Limited.

Siddiqui, M. A., \& Shoaib, A. (2011). Measuring performance through capital structure: Evidence from banking sector of Pakistan. African Journal of Business Management, 5(5), 1871-1879.

Tarawneh, M. (2006). A Comparison of Financial Performance in the Banking Sector: Some Evidence from Omani Commercial Banks. International Research Journal of Finance and Economics, 3, 101-112.

Yap, B. C. F., Munuswamy, S. \& Mohamed, Z. B. (2012). Evaluating Company Failure in Malaysia Using Financial Ratios and Logistic Regression. Asian Journal of Finance \& Accounting, 4(1), 330-334.

\section{Copyright Disclaimer}

Copyright for this article is retained by the author(s), with first publication rights granted to the journal.

This is an open-access article distributed under the terms and conditions of the Creative Commons Attribution license (http://creativecommons.org/licenses/by/4.0/) 